Original Research Article

\title{
Study of diuretic activity of aqueous extract of amaranthus spinosus linn on rats
}

\author{
Shravani Potllapalli ${ }^{1}$, Jagannath Narumalla ${ }^{1}$, Naga Teja Pavani A. ${ }^{2}$, Damodaram Govindadas ${ }^{1}$, \\ Somashekar S. Chikkannasetty ${ }^{3}$
}

${ }^{1}$ Department of Pharmacology, SVS Medical College,

Mahabubnagar, Telangana,

India

${ }^{2}$ Department of Pharmacology,

Kamineni Academy of Medical

Sciences and Research Center,

Hyderabad, Telangana, India

${ }^{3}$ Department of Pharmacology,

ESIC Medical College,

Gulberga, Karnataka, India

Received: 26 October 2016

Accepted: 23 November 2016

*Correspondence to:

Dr. Narumalla Jagannath,

Email:

pharmacology.jae@gmail.com

Copyright: (C) the author(s), publisher and licensee Medip Academy. This is an openaccess article distributed under the terms of the Creative Commons Attribution NonCommercial License, which permits unrestricted noncommercial use, distribution, and reproduction in any medium, provided the original work is properly cited.

\begin{abstract}
Background: Traditional Siddha medicine literature claims that the Amaranthus spinosus Linn. Whole plant possesses diuretic property. The aim of the present study is to investigate the diuretic activity of aqueous extract of amaranthus spinosus linn on rats.

Methods: The rats were randomly divided into four groups of six animals each and deprived of food for 18 hours before the experiments. Control (Group I) rats were treated with Normal saline $(5 \mathrm{ml} / \mathrm{Kg}$,) and Standard (Group II) rats were administered furosemide $15 \mathrm{mg} / \mathrm{Kg}$, I.P. Group III and IV were treated with Aqueous extract of Amaranthus spinosus Linn (AEAS) 250 and $500 \mathrm{mg} / \mathrm{kg}$ in normal saline respectively, The urine was collected after 5 and 24 hours. The urine volume and the total concentration of $\mathrm{Na}+\mathrm{K}+$, and $\mathrm{Cl}$ - in the urine were estimated. The data were presented as mean \pm standard deviation and analyzed using one-way analysis of variance and Student's "t"-test. $P<0.05$ was considered statistically significant. Conventional windows software was used for statistical analysis.

Results: Urine analysis showed that $\mathrm{Na}+\mathrm{K}+$, and $\mathrm{Cl}$ - levels were significantly $(\mathrm{p}<0.05)$ increased with AEAS 250 and $500 \mathrm{mg} / \mathrm{kg}$ as rats treated with furosemide $15 \mathrm{mg} / \mathrm{kg}$. Urine volume is significantly $(\mathrm{p}<0.05)$ increased in rats treated with drugs (AEAS $500 \mathrm{mg} / \mathrm{kg}$ and furosemide $15 \mathrm{mg} / \mathrm{kg}$ ) compared to normal saline $25 \mathrm{ml} / \mathrm{Kg}$, treated rats at 5 and 24 hours.

Conclusions: These data suggest that AEAS has produced notable diuretic effect which appeared to be comparable to that produced by the standard diuretic furosemide.
\end{abstract}

Keywords: Amaranthus spinosus linn, Diuretic activity, Furosemide

\section{INTRODUCTION}

Diuretics are drugs that increase the rate of urine flow along with $\mathrm{Na}+$ excretion and are used to adjust the volume and composition of body fluids in a variety of clinical situations. Naturally occurring diuretics include caffeine in coffee, tea and cola which inhibit $\mathrm{Na}+$ reabsorption and alcohol in beer, wine and mixed drinks which inhibit secretion of anti-diuretic hormone (ADH). ${ }^{1}$

Drug induced diuresis is beneficial in many lifethreatening disease conditions such as congestive heart failure, nephrotic syndrome, cirrhosis, renal failure, hypertension and toxemia of pregnancy. Most diuretic drugs have an adverse effect on quality of life including impotence, fatigue and weakness. ${ }^{1}$ Because of these disadvantages, a natural diuretic with reduced or no toxic effects is therefore essential. Many plants are used by folklore as medicine for diuretic and also for the treatment of various diseases. The diuretic activity has been documented for Tectona grandis Salvia Officinalis and Centratherum anthelminticum. ${ }^{1-3}$ 
The plants products are in use for the treatment of various diseases for thousands of years. Amaranthus spinosus Linn is a popular plant belonging to Amaranthaceae family. Literature in Siddha medicine claims that the decoction of Amaranthus spinosus has potent diuretic activity and reduces edema secondary to cardiovascular diseases and kidney diseases. ${ }^{4,5}$ It is used as a traditional medicine to treat diabetes, the roots are known for their effective diuretic, antipyretic activity and also used to treat indigestion and toothache. ${ }^{6-9}$ The leaves are used for gastroenteritis, gallbladder inflammation, abscesses and arthritis. ${ }^{10}$

The diuretic activity of the Amaranthus spinosus Linn are less reported so far, though it is used in folklore medicine. Thus, it was considered worthwhile to take up such investigation in detail.

Hence, the present study was aimed to explore the diuretic activity of Aqueous Extract of Amaranthus spinosus Linn (AEAS) on rats.

\section{METHODS}

Healthy albino rats of either sex weighing between 220$270 \mathrm{~g}$, maintained in identical conditions were selected. They were housed in colony cages with free access to food and water ad libitum. They were acclimatized for 7 days before they were used. Pregnant rats were excluded from the study.

\section{Drugs and chemicals}

Furosemide is used as a standard reference and was given in the dose of $15 \mathrm{mg} / \mathrm{kg}$ body weight. Diagnostic kits for urine electrolyte concentrations of sodium, potassium and chloride purchased from Crest Bio systems (Division of Coral Clinical Systems, Goa).

\section{Amaranthus spinosus linn}

The whole plant of Amaranthus Spinosus L. was collected from Tamilnadu, India. The whole plant was dried under shade, powdered and stored in an airtight container. The sample of the AEAS was extracted by using soxhlet.

Two different doses of $250 \mathrm{mg} / \mathrm{kg}$ and $500 \mathrm{mg} / \mathrm{kg}$ were selected and dissolved in distilled water, so that the concentration mentioned was obtained respectively.

\section{Acute toxicity study}

The Aqueous extract of the bark of Amaranthus spinosus L. has a relatively low toxicity LD50 value of 1450 $\mathrm{mg} / \mathrm{kg}{ }^{11}$

\section{Evaluation of diuretic activity}

Diuretic activity was determined by the methods of Patel $\mathrm{R}$ et al with minor modifications. ${ }^{12}$

All the rats were kept in good experimental condition and deprived of food for 18 hours before the experiments. $5 \mathrm{ml} / \mathrm{kg}$ of Normal saline $(0.9 \%)$ was given orally to the rats before administration of drug or extracts.

The rats were randomly divided into four groups of six animals each and the drug treatment pattern was as follows:

- (Group I) Control - Given $5 \mathrm{ml} / \mathrm{kg}$ body weight of normal saline;

- (Group II) Standard - Furosemide $15 \mathrm{mg} / \mathrm{kg}$ body weight.

- (Group III) Aqueous extract of Amaranthus spinosus L.- $250 \mathrm{mg} / \mathrm{kg}$ body weight

- (Group IV) Aqueous extract of Amaranthus spinosus L.-500 mg/kg body weight

Immediately after dosing, the animals were placed in metabolic cages specially designed to collect urine. The urine was collected and measured after 5 and 24 hours with a graduated measuring cylinder.

At the end of 24hours the concentration of sodium, potassium and chloride in urine were estimated. The mean urine volumes were determined and diuretic potency was assessed by comparison of urine excretion and biochemical parameters (sodium, potassium and chloride) due to extracts and standard drug furosemide with respect to the normal control.

\section{Statistical analysis}

The results were expressed as the mean \pm SD and the data was analyzed using one-way analysis of variance (ANOVA) followed by student's t-test. $\mathrm{P}<0.05$ was considered as significant.

\section{RESULTS}

\section{Diuretic activity of amaranthus spinosus linn}

In the present study, AEAS was assessed for its diuretic activity in rats and the results obtained were recorded.

\section{Urine analysis}

Urine analysis showed that sodium, potassium and chloride levels are increased in Groups II, III, IV compared to Group I (Table 1).

This data indicate that Sodium, Potassium and Chloride levels were significantly $(\mathrm{p}<0.05)$ increased with test drug 250 and $500 \mathrm{mg} / \mathrm{kg}$ bd.wt aqueous extract of Amaranthus spinosus L (Group III and Group IV) as seen 
in rats treated with furosemide (Group II, standard drug

$15 \mathrm{mg} / \mathrm{kg}$ bd.wt) compared to Normal (Group I).

Table 1: Comparison of effect of furosemide and AEAS on biochemical parameters in rats.

\begin{tabular}{|c|c|c|c|c|}
\hline \multirow[b]{2}{*}{ Groups } & \multirow{2}{*}{ Dose } & \multicolumn{3}{|c|}{ Urinary electrolyte concentration (24hr) } \\
\hline & & $\mathrm{Na}^{+}(\mathbf{m E q} / \mathbf{l})$ & $\mathrm{K}^{+}(\mathbf{m E q} \mathbf{l})$ & $\mathrm{Cl}^{-}(\mathrm{mEq} / \mathrm{l})$ \\
\hline Group I control (N.S) & $5 \mathrm{ml} / \mathrm{kg}$ bd, wt & $84.3 \pm 16.1$ & $38.10 \pm 10.25$ & $97 \pm 8.8$ \\
\hline Group II standard (Furosemide) & $15 \mathrm{mg} / \mathrm{kg}$ bd.wt) & $128 \pm 16.1^{*}$ & $65.91 \pm 7.75^{* *}$ & $196 \pm 7.4^{* * *}$ \\
\hline Group III (AEAS) & $250 \mathrm{mg} / \mathrm{kg}$ bd.wt) & $101 \pm 8.5^{*}$ & $56.41 \pm 3.50^{* * *}$ & $133.3 \pm 1.8^{* *}$ \\
\hline Group IV (AEAS) & $500 \mathrm{mg} / \mathrm{kg}$ bd.wt) & $116 \pm 15.3^{* * *}$ & $58.66 \pm 7.72^{* *}$ & $179.3 \pm 9.1^{* * *}$ \\
\hline
\end{tabular}

N.S = Normal saline; AEAS $=$ Aqueous Extract of Amaranthus Spinosus

Values are expressed as mean \pm S.D.

${ }^{*} \mathrm{p}<0.05,{ }^{*} \mathrm{cp}<0.005$ and $* * * \mathrm{p}<0.001$ compared with control (ANOVA followed by Student unpaired ' $\mathrm{t}$ ' test).

\section{Urine volume}

An increase in urine volume was observed in Groups II, III and IV compared to Group I (Control) at $5^{\text {th }}$ and $24^{\text {th }}$ hour (Table 2).

Table 2: Comparison of effect of furosemide and AEAS on volume of urine in rats.

\begin{tabular}{|llll|}
\hline Groups & Dose & \multicolumn{2}{l|}{ Volume of urine $(\mathbf{m l} / \mathbf{1 0 0 g})$} \\
\hline $\begin{array}{l}\text { Group I } \\
\text { control (N.S) }\end{array}$ & $\begin{array}{l}5 \mathrm{ml} / \mathrm{kg} \\
\text { bd,wt }\end{array}$ & $0.43 \pm 0.73$ & $2.56 \pm 0.44$ \\
\hline $\begin{array}{l}\text { Group II } \\
\text { standarad } \\
\text { (Furosemide) }\end{array}$ & $\begin{array}{l}15 \mathrm{mg} / \mathrm{kg} \\
\text { bd.wt }\end{array}$ & $1.25 \pm 0.15^{*}$ & $3.73 \pm 0.51^{* * *}$ \\
\hline $\begin{array}{l}\text { Group III } \\
\text { (AEAS) }\end{array}$ & $\begin{array}{l}250 \mathrm{mg} / \mathrm{kg} \\
\text { bd.wt }\end{array}$ & $0.54 \pm 0.06$ & $2.79 \pm 0.45$ \\
\hline $\begin{array}{l}\text { Group IV } \\
\text { (AEAS) }\end{array}$ & $\begin{array}{l}500 \mathrm{mg} / \mathrm{kg} \\
\text { bd.wt }\end{array}$ & $1.15 \pm 0.05^{*}$ & $3.45 \pm 0.38^{* *}$ \\
\hline
\end{tabular}

N.S $=$ Normal saline; AEAS $=$ Aqueous Extract of Amaranthus Spinosus

Values are expressed as mean \pm S.D.

$* \mathrm{p}<0.05, * * \mathrm{p}<0.005$ and $* * * \mathrm{p}<0.001$ compared with control (ANOVA followed by Student unpaired 't' test).

From the data significant $(\mathrm{p}<0.05)$ increase in urine volume is seen only in rats treated with $500 \mathrm{mg} / \mathrm{kg}$ of aqueous extract of Amaranthus spinosus $\mathrm{L}$ and Furosemide $15 \mathrm{mg} / \mathrm{kg}$ bd. wt (Group II and Group IV) at $5^{\text {th }}$ and $24^{\text {th }}$ hour.

\section{DISCUSSION}

Diuresis is the condition which causes a net loss of $\mathrm{Na}+$ and water in urine. Diuretics relieve pulmonary congestion and peripheral edema. These agents are useful in reducing the syndrome of volume overload, decrease cardiac workload, oxygen demand and plasma volume. Thus, diuretics play an important role in congestive heart failure patients.

The present study evaluated the diuretic effect of Amaranthus spinosus Linn in rats. AEAS $250 \mathrm{mg} / \mathrm{kg}$ and
$500 \mathrm{mg} / \mathrm{kg}$ body weight showed a significant increase in urine volume after $5 \mathrm{hr}$ and $24 \mathrm{hr}$. It also showed a significant increase in urinary execration of $\mathrm{Na}+\mathrm{K}+$ and $\mathrm{Cl}$ - which is statistically significant.

The AEAS may produce the diuretic effect by increasing the excretion of $\mathrm{Na}+, \mathrm{K}+$, and $\mathrm{Cl}-$. The control of plasma sodium is important in the regulation of blood volume and pressure; the control of plasma potassium is required to maintain proper function of cardiac and skeletal muscles. The regulation of $\mathrm{Na}+\mathrm{K}+$ balance is also intimately related to renal control of acid-base balance. ${ }^{2}$

The results of the present investigation showed that the AEAS is most effective in increasing urinary electrolyte concentration of all the ions i.e., $\mathrm{Na}+, \mathrm{K}+$, and $\mathrm{Cl}$ - similar to that of standard i.e (furosemide). Furosemide mainly acts due to the inhibition of $\mathrm{Na}+/ \mathrm{K}+/ 2 \mathrm{Cl}$-symport. So inhibition of $\mathrm{Na}+/ \mathrm{K}+/ 2 \mathrm{Cl}$ symport may be the possible mechanism for Amaranthus spinosus similar to that of the standard. Still the exact underlying mechanism of diuretic activity of Amaranthus spinosus is unknown so further studies are recommended.

The preliminary phytochemical studies have confirmed the presence of carbohydrates, glycosides, saponins, terpenoids, phenolic compounds, tannins, alkaloids, steroids and flavonoids in Amaranthus spinosus. ${ }^{13,14,16,17}$ Previous studies have also demonstrated that there are several phytochemicals such as flavonoids, saponins and terpenoids which could be responsible for plants diuretic effect. $^{2,15}$

Hence, the diuretic effect of AEAS may be due to the presence of saponins, flavonoids and terpenoids and flavonoids which may act individually or in combination to produce diuresis.

\section{CONCLUSION}

On the basis of the above result it was suggested that, the Aqueous Extract of Amaranthus spinosus Linn possesses significant diuretic activity. The underlying mechanism may be inhibition of $\mathrm{Na}+/ \mathrm{K}+/ 2 \mathrm{Cl}$ - symport. This property 
may be mediated by the presence of the active constituents such as flavonoids, saponins and terpenoids in the Aqueous Extract of Amaranthus spinosus Linn. Further studies at molecular level are required to establish exact mechanism of action.

Funding: No funding sources Conflict of interest: None declared

Ethical approval: The study was approved by the Institutional Ethics Committee

\section{REFERENCES}

1. Koti BC, Purnima A. Diuretic activity of extracts of Centratherumant helminticum. Int J Green Pharm. 2008;2:228-31.

2. Kore KJ, Jadhavpradip, Shete RV, Shetty SC. Diuretic activity of Tectona grandis leaves aqueous extract in wistar rats. IJPRD. 2011:3;141-46.

3. Upendrabhadoriya, Swetatiwary, Sharma P, Bankey S, Mourya M. Diuretic activity of extract of Salvia officinalis L. Asian Journal of Pharmacy and Life Science. 2011:1:24-8.

4. Mudhaliyar M. Medica SM. The Reliance Printers, India; 1998:342.

5. Varier PS. Indian Medicinal Plants. Orient Longman, India; 2005:121-124.

6. Khare CP. Indian medicinal plants illustrated dictionary. Springer published, New Delhi; 2014:41-42.

7. Azhar-ul-Haq, Malik A, Khan AU, Shah MR, Muhammad P. Spinoside, new coumaroyl flavone glycoside from Amaranthus spinosus. 2004;27:1216-9.

8. Buragohain J. Folk medicinal plants used in gynecological disorders in Tinsukia district, Assam, India. Fitoterapia. 2008;5:388-92.

9. Hilou A, Nacoulmaa OG, Guiguemdeb TR. In vivo antimalarial activities of extracts from Amaranthus spinosus L, Boerhaavia EL. in mice. Journal of Ethnopharmacology. 2006;103:236-40.

10. Ibewuike J, Ogundaini AO, Bohlin L, Ogungbamila FO. Anti-Inflammatory Activity of Selected Nigerian Medicinal Plants. J. Nat. Prod. And Med. 1997;1:10-4.

11. Cai Y, Sun M, Corke H. Antioxidant activity of betalains from plants of the Amaranthaceae. J Agric Food Chem. 2003;51:2288-94.

12. Patel R, Mahobia NK, Gendle R, Kauskik B, Singh SK. Diuretic activity of leaves of Plectranthus amboinicus (LOUR) Spreng in male albino rats. Phcog Res. 2010;2:86-8.

13. Jhade D, Ahirwar D, Jain R, Sharma N, Gupta S. Pharmacognostic standardization, physico and phytochemical evaluation of Amaranthus Spinosus linn. Root. J Young Pharm. 2011;3:221-5.

14. Hilou A, Nacoulma OG, Guiguemde TR. In vivo antimalarial activities of extracts from Amaranthus spinosus L. and Boerhaavi aerecta L. in mice. $\mathrm{J}$ Ethnopharmacol. 2006;103:236-40.

15. Naik ND, Kalugonda MK, Jayasri P, Elumalai A. Evulation of diuretic activity of Sidaspinosa Linn leaves extract. J. chem.pharm.res. 2011;6:1004-8.

16. Baral M, Chakraborty S, Chakraborty P. Evaluation of anthelmintic and anti-inflammatory activity of Amaranthus Spinosus Linn. Int J Curr Pharm Res. 2010;2(4):4447.

17. Yadav U, Hugo A, Boon EK. Indigenous use and bio-efficacy of medicinal plants in Rasuwa district, central Nepal. Journal of Ethano biology and Ethano medicine. 2010;6:3.

Cite this article as: Potllapalli S, Narumalla J, Naga TPA, Govindadas D, Chikkannasetty SS. Study of diuretic activity of aqueous extract of amaranthus spinosus linn on rats. Int J Basic Clin Pharmacol 2017;6:141-4. 